\title{
ANALISIS KEMAMPUAN KOMUNIKASI MATEMATIS SISWA SMP DI KOTA CIMAHI PADA MATERI STATISTIKA
}

\author{
Niasih $^{1}$, Siti Romlah ${ }^{2}$, Luvy Sylviana Zhanty ${ }^{3}$ \\ ${ }^{1,2,3}$ IKIP SILIWANGI, Jalan Terusan Jenderal Sudirman, Cimahi Tengah, Kota Cimahi, Jawa Barat \\ niasih980@gmail.com
}

\begin{abstract}
This article is an analysis of the results of tests about the mathematical communication skills of eighth grade students of junior high school. This analysis intends to find out and identify the types of difficulties faced by students and to determine the level of mathematical communication of junior high school students in Cimahi City. This analysis is a descriptive qualitative study. Students of class VIII of Junior High School were used as samples. The test instruments were distributed as many as 5 items about statistica material in the form of a description. Processing data using Microsoft Excel and SPSS. V.23. The results of the analysis obtained based on written tests distributed to students showed that the level of mathematical communication skills of junior high school students in Cimahi City had mathematical communication with low criteria.
\end{abstract}

Keywords: Mathematical Communcation, Statistic

\begin{abstract}
Abstrak
Cara pandang guru terhadap matematika akan berpengaruh terhadap cara pengajarannya. Calon guru sering menganggap bahwa belajar mata kuliah lanjutan pada perguruan tinggi tidak berguna bagi pengajaran mereka nantinya di sekolah. Tujuan dari penelitian ini adalah untuk menggali tentang kompetensi apa saja yang dikembangkan dalam diri mahasiswa calon guru selama perkuliahan aljabar abstrak serta bagaimana pemahaman mahasiswa calon guru terhadap pentingnya belajar aljabar abstrak. Metode yang digunakan dalam penelitian ini adalah metode deskriptif kualitatif. Mahasiswa diminta untuk mengamati perkembangan kognitif dalam diri mereka dari setiap pengalaman belajar aljabar abstrak. Data dikumpulkan melalui angket, refleksi dan wawancara mahasiswa. Subjek penelitian sebanyak 90 mahasiswa yang mengikuti mata kuliah aljabar Abstrak. Hasil penelitian diperoleh 1) Secara umum kompetensi matematik mahasiswa semakin berkembang setelah perkuliahan aljabar abstrak melalui pengalaman belajar mahasiswa, 2) Mahasiswa setuju bahwa mata kuliah aljabar abstrak relevan bagi mereka sebagai seorang pendidik di tingkat sekolah dikarenakan dengan belajar aljabar abstrak membuat mahasiswa dapat mengembangkan kompetensi dan konsep-konsep matematika. Penelitian ini memberikan gambaran perlunya belajar konsep matematika yang kompleks bagi seorang calon guru.
\end{abstract}

Kata kunci: Aljabar Abstrak, Calon guru, Relevansi

Pendidikan adalah pembelajaran paling mendasar yang wajib setiap individu dapatkan baik secara formal maupun informal (Chotimah, 2019). Pendidikan berguna untuk kehidupan dimasa kini dan mendatang (Maharani, 2018). Dengan adanya pendidikan manusia dapat belajar demi mencapai tujuan hidupnya. Dalam Undang-Undang Nomor 20 Tahun 2003 tentang Sistem Pendidikan Nasional menyatakan pembelajaran diartikan sebagai proses interaksi peserta didik dengan pendidik dan sumber belajar pada suatu lingkungan belajar.

Kualitas pendidikan di Indonesia di nilai masih tergolong rendah, hal ini dapat terlihat dari hasil tes Trend In International Matematics and Sciense Study (TIMSS), lembaga yang mengukur dan membandingkan kemampuan matematis siswa-siswi antar Negara, penguasaan matematika siswa tingkat 8. Tahun 1999 Indonesia menduduki peringkat ke 32 dari 38 Negara yang diteilti. Tahun 2003 
Analisis Kemampuan Komunikasi Matematis Siswa Smp Di Kota Cimahi Pada Materi Statistika, Niasih, Siti Romlah,

Indonesia menduduki peringkat ke 36 dari 45 yang di teliti, pada tahun 2007 Indonesia menduduki peringkat ke 41 dari 48 negara yang di teliti rerata skor yang diperoleh siswa-siswi Indonesia adalah 397. Skor ini masih jauh dari skor Internasional yaitu 500 (Setiawan, 2015).

Salah satu tujuan umum pembelajaran matematika yang disusun oleh pemerintah melalui Badan Standar Nasional Pendidikan (BSNP) yang tertuang dalam Permendiknas No. 22 tahun 2006 Tentang Standar Isi, menegaskan bahwa pembelajaran matematika bertujuan menjadikan peserta didik memiliki kemampuan dalam mengkomunikasikan gagasan dengan simbol, tabel, diagram, atau media lain untuk memperjelas keadaan atau masalah. (Rohaeti, 2018, Sugandi, 2018, Nurhayati, 2019).

Untuk siswa yang memiliki tingkat kecerdasan tinggi, sikap dan tindakan serta cara mengajar yang dilakukan oleh guru tidak menjadi masalah. Tetapi, bagi siswa yang memiliki tingkat kecerdasan rata-rata, dan rendah pelajaran matematika akan menjemukkan dan mengakibatkan tidak senang belajar matematika (Bernard, 2019, Hidayat, 2018, ), dan kecenderungan siswa bergantung pada buku teks saat belajar (Akbar, et. al, 2018). Komunikasi matematika sangatlah penting dan perlu mendapat perhatian. Komunikasi matematik adalah kemampuan siswa dalam menjelaskan idea, situasi dan relasi matematik, secara tulisan dengan gambar, membaca presentasi matematika tertulis dan menyusun pertanyaan yang relevan menyusun argument. Salah satu alternatif model pembelajaran yaitu dengan menggunakan model pembelajaran think-pair-share (TPS) (Nurjaman, 2015).

Menurut Bernard (2015) kemampuan komunikasi sangat penting untuk siswa miliki supaya siswa dapat memahami permasalahan matematika yang diberikan dan siswa mampu mengungkapkan ide serta gagasan dalam menyelesaikan persoalan matematika serta menciptakan siswa untuk berpikir kritis, logis, kreatif dan mandiri (Islamiah, et. Al., 2018:48).

Kurnia (2017) dalam R.S Dilla menyatakan dalam suatu diskusi yang dilaksanakan oleh peneliti dengan beberapa guru SMP terungkap siswa masih kurang dalam komunikasi matematis, baik komunikasi lisan maupun tulisan. Sedangkan pandangan kedua ahli Silver dan Smith (Wahid Umar, 2012:1) ternyata kemampuan komunikasi matematis memang perlu ditumbuhkembangkan di kalangan siswa. Hal ini diperkuat oleh Baroody (1993: 107), bahwa pembelajaran harus dapat membantu siswa mengkomunikasikan ide matematika melalui lima aspek komunikasi yaitu representing, listening, reading, discussing dan writing. Selanjutnya disebutkan sedikitnya ada dua alasan penting, mengapa komunikasi dalam pembelajaran matematika perlu ditumbuhkembangkan di kalangan siswa. Pertama, mathematics as language, artinya matematika tidak hanya sekedar alat bantu berpikir ( $a$ tool to aid thinking), alat untuk menemukan pola, menyelesaikan masalah atau mengambil kesimpulan, tetapi matematika juga " an invaluable tool for communicating a Variety of ideas clearly, precisely, and succinctly. Kedua, mathematics learning as social activity: artinya sebagai aktivitas sosial dalam pembelajaran matematika, sebagai wahana interaksi antar siswa, serta sebagai alat komunikasi antara guru dan siswa.

Sumarmo (2003) dalam Fahradina dkk mengemukakan disamping pentingnya Kemampuan komunikasi dalam matematika, juga diperlukan sikap yang harus dimiliki oleh siswa diantaranya 
adalah inisiatif belajar, memonitor, mengatur, dan mengontrol belajar, dan mengevaluasi proses dan hasil belajar, yang merupakan indikator dari kemandirian belajar siswa. Berdasarkan beberapa pendapat ahli dapat disimpulkan bahwa komunikasi matematis merupakan satu kemampuan dasar matematis yang esensial dan perlu dimiliki oleh siswa sekolah menengah (SM).

Kegiatan-kegiatan ini dapat dilakukan melalui pemberian soal matematika yang berhubungan dengan grafik, bagan, diagram, lambang, symbol. Khadijah, Maya, \& Setiawan (2018) mengemukakan bahwa tabel, diagram, dan grafik dapat menuntun siswa untuk membuat kesimpulan, prediksi, dan pertanyaan. Melalui pembelajran yang aktif dan dapat memicu daya nalar siswa sehingga pembelajaran lebih bermakna yaitu dengan menggunakan pembelajaran kontekstual (Chotimah, 2018).

Berdasarkan hal tersebut, perlu dilakukan analisis yang menjadi urgensi dari permasalahan tentang seberapa besar kemampuan komunikasi matematis siswa SMP di Kota Cimahi pada materi statistika. Materi statistika menjelaskan tentang memahami konsep dasar teknik penyajian data dalam bentuk tabel dan diagram atau grafik, menafsirkan makna dari diagram atau grafik yang disajikan, menentukan mean, modus, dan median data tunggal. Adapun indikator-indikator kemampuan komunikasi matematis yang dikemukakan oleh Sumarmo (2006) diantaranya:

a. Menghubungkan benda nyata, gambar, dan diagram ke dalam ide matematika;

b. Menjelaskan ide, situasi dan relasi matematika, secara tulisan;

c. Menyatakan peristiwa sehari-hari dalam bahasa atau simbol matematika;

d. Mendengarkan, mendiskusi, dan menulis tentang matematika;

e. Membuat konjektur, menyusun argument, merumuskan definisi dan generalisasi.

Peneliti akan melakukan studi pendahuluan dengan judul "Analisis Kemampuan Komunikasi Matematis Siswa SMP di Kota Cimahi Pada Materi Statistika”.

\section{METODE PENELITIAN}

Penelitian ini merupakan kualitatif deskriptif, yang bertujuan memaparkan penjelasan bagaimana cara siswa dalam memecahkan soal statistika berdasarkan kemampuan komunikasi matematis siswa tersebut. Data penelitian ini berupa jawaban tertulis yang diperoleh dari tes tertulis yang dilakukan sebanyak 32 orang siswa kelas VIII digunakan sebagai sampel yaitu siswa SMP yang berada di Kota Cimahi. Adapun soal yang diberikan yaitu 5 butir pertanyaan dengan materi statistika dalam bentuk uraian.

\section{HASIL DAN PEMBAHASAN}

Penelitian ini dilakukan pada siswa di kelas VIII SMP di Kota Cimahi. Berikut ini disajikan tabel persentase jawaban siswa tiap butir soal. 


\section{Tabel 1}

Persentase Jawaban Siswa Tiap Butir Soal

\begin{tabular}{|c|c|c|c|}
\hline \multirow{2}{*}{$\begin{array}{l}\text { No } \\
\text { Soal }\end{array}$} & \multirow{2}{*}{ Indikator } & \multicolumn{2}{|c|}{ Rata-Rata } \\
\hline & & Skala 4 & $\%$ \\
\hline 1 & $\begin{array}{l}\text { Menghubungkan benda nyata, gambar dan diagram kedalam ide } \\
\text { matematika }\end{array}$ & 1,11 & $27,81 \%$ \\
\hline 2 & Menjelaskan ide, situasi dan relasi matematika, secara tulisan & 0,96 & $24,02 \%$ \\
\hline 3 & $\begin{array}{l}\text { Menyatakan peristiwa sehari-hari dalam bahasa atau simbol } \\
\text { matematika }\end{array}$ & 0,83 & $20,84 \%$ \\
\hline 4 & Mendengarkan, mendiskusi dan menulis tentang matematika & 1,21 & $30,17 \%$ \\
\hline 5 & $\begin{array}{l}\text { Membuat konjektur, menyusun argumen, merumuskan definisi dan } \\
\text { generalisasi }\end{array}$ & 1,10 & $27,49 \%$ \\
\hline & Total Kemampuan Komunikasi Matematis & 3,64 & $26,00 \%$ \\
\hline
\end{tabular}

Setelah pemberian skor pada jawaban siswa didasarkan pada indikator dicapai. Selanjutnya skor perindikator dan skor keseluruhan siswa dikonversi dalam bentuk nilai skala (1-100) serta menafsirkan data sesuai kriteria pemahaman berdasarkan Arikunto (Khadijah, Maya, \& Setiawan, 2018). Data dikatagorikan dengan menggunakan batasan sebagai berikut:

Tabel 2

Kriteria Data

\begin{tabular}{cc}
\hline Persentase & Kriteria \\
\hline $81 \%-100 \%$ & Baik sekali \\
$61 \%-80 \%$ & Baik \\
$41 \%-60 \%$ & Cukup \\
$21 \%-40 \%$ & Kurang \\
$0 \%-20 \%$ & Kurang Sekali \\
\hline
\end{tabular}

Berdasarkan Tabel 2 kriteria data menunjukan bahwa rata-rata skor keseluruhan soal dari semua siswa termasuk kedalam kriteria kurang atau rendah yaitu 26,00\%.

\section{Analisis soal no 1}

Butir soal pertama dengan indikator menghubungkan benda nyata, gambar dan diagram kedalam ide matematika adalah sebagai berikut:

Perhatikan diagram dibawah ini!

a. Lengkapilah diagram di bawah ini dengan judul yang menurutmu benar!

b. Susunlah cerita singkat yang sesuai dengan grafik di bawah! 


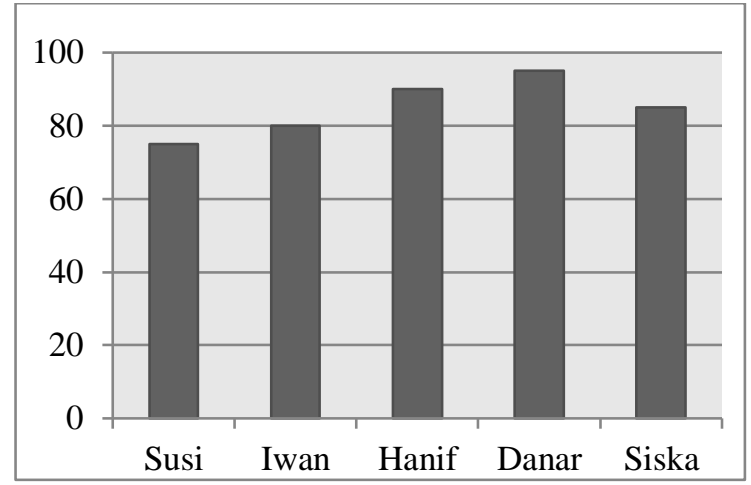

Jawaban siswa 1

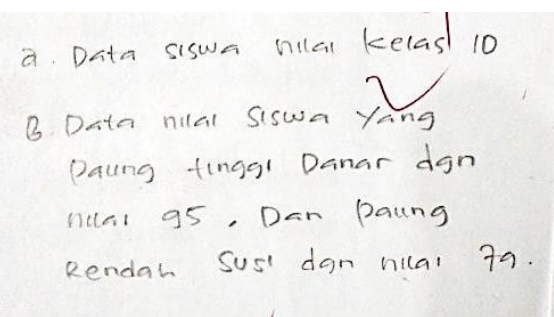

(a)

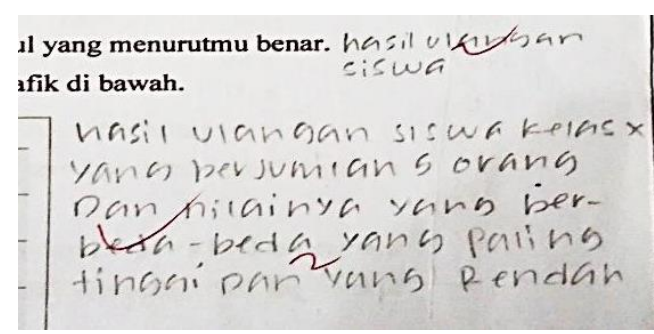

(b)

Gambar 1 (a) benar (b) mendekati benar.

Pada gambar 1a, siswa menjawab benar sesuai yang diharapkan karena menjelaskan kesimpulan sesuai data pada soal dengan menyebutkan nilai tertinggi didapat oleh Danar yaitu 95 dan nilai terendah adalah susi dengan nilai 79. Jawaban pada gambar $1 \mathrm{~b}$ dapat dikatakan benar atau mendekati benar, karena pada soal no 1 ini siswa hanya menyimpulkan dan melengkapi soal berdasarkan data yang diberikan.

Kemungkinan kesulitan yang terjadi pada soal no 1 ini sangat rendah karena soal no 1 tergolong soal mudah, siswa mudah menjawab tetapi masih kurang sempurna dalam menarik kesimpulan. Hal itu disebabkan siswa kurang teliti dalam menjawab pertanyaan pada soal tersebut, dan tidak memperhatikan secara benar data yang diberikan. Misalnya siswa menyimpulkan bahwa soal no 1 adalah data nilai tertinggi dan terendah saja.

\section{Analisis soal no 2}

Butir soal kedua dengan indikator Menjelaskan ide, situasi dan relasi matematika, secara tulisan sebagai berikut:

Selama epidemi influenza, banyaknya siswa tidak masuk di suatu sekolah dalam sepuluh hari berturut-turut adalah sebagai berikut:

\begin{tabular}{|c|c|c|c|c|c|c|c|c|c|c|}
\hline Hari & 1 & 2 & 3 & 4 & 5 & 6 & 7 & 8 & 9 & 10 \\
\hline $\begin{array}{c}\text { Banyaknya } \\
\text { absen }\end{array}$ & 30 & 35 & 60 & 78 & 87 & 83 & 69 & 43 & 30 & 29 \\
\hline
\end{tabular}


a. Gambarkan diagram garis dari data di atas.

b. Berdasarkan diagram garis yang telah dibuat, nayatakan dengan kalimatmu sendiri tentang kejadian epidemic influenza yang menimpa pada sekolah itu.

Jawaban siswa 1

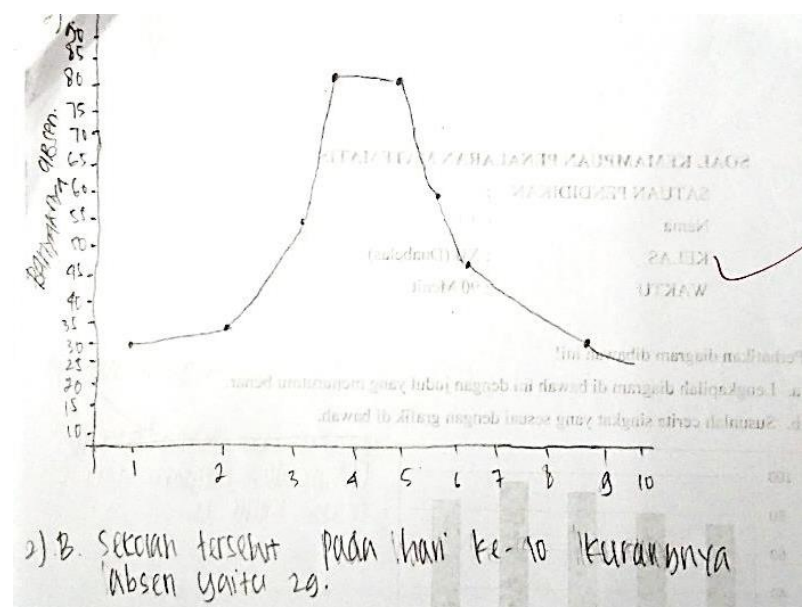

Gambar 2a. Jawaban siswa 1 soal no 2

Jawaban siswa 1 menggambarkan diagram garis tanpa titik-titik putus, untuk no 2a jawaban ini kurang lengkap. Pada garis horizontal tidak dilengkap keterangan hari, sehingga terkesan menjawab soal dengan asal-asalan dan terburu-buru. Untuk jawaban $2 \mathrm{~b}$ adalah menyimpulkan dari apa yang telah digambarkan sebelumnya. Pada jawaban siswa 1 tersebut siswa bermaksud menyimpulkan banyaknya absen pada hari ke-10 yaitu 29 orang. Namun, gambar diagram garis yang digambarkan tidak menunjukan 29 orang.

Jawaban siswa 2

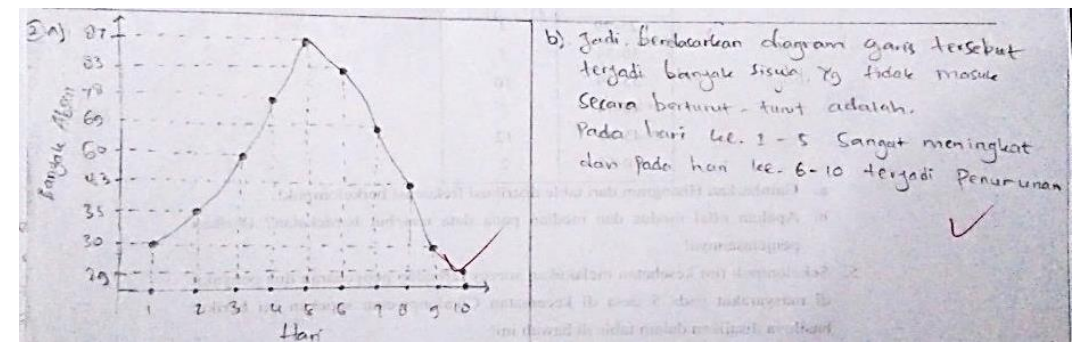

Gambar 2b. Jawaban siswa 2 soal no 2

Jawaban siswa 2 mendekati benar, karena pada jawaban 2a siswa tersebut menggambarkan diagram dengan teliti hal ini terbukti dalam menghubungkan antar titik koordinat. Jawaban $2 \mathrm{~b}$ juga mendekati jawaban yang diharapkan, karena mampu menarik kesimpulan berdasarkan gambar pada jawaban sebelumnya.

Kendala yang dihadapi pada soal no 2 adalah siswa masih belum menguasai cara menggambar digram garis dengan baik. Dalam soal tersebut juga siswa dituntut menyimpulkan dari apa yang telah 
digambar sebelumnya, namun kenyataannya siswa masih kesulitan menarik kesimpulan dengan tepat.

\section{Analisis soal no 3}

Butir soal ketiga dengan indikator Menyatakan peristiwa sehari-hari dalam bahasa atau simbol matematika, adalah sebagai berikut:

Peserta ujian matematika kelas xii terdiri atas 24 orang siswa kelas A dan 23 orang siswa kelas B. Nilai rata-rata seluruh siswa yang mengikuti ujian adalah 7,5 sedangkan nilai rata-rata siswa kelas A adalah ..

a. Buatkan tabel dari soal tersebut

b. Tentukan nilai rata-rata siswa kelas B

Jawaban siswa 1

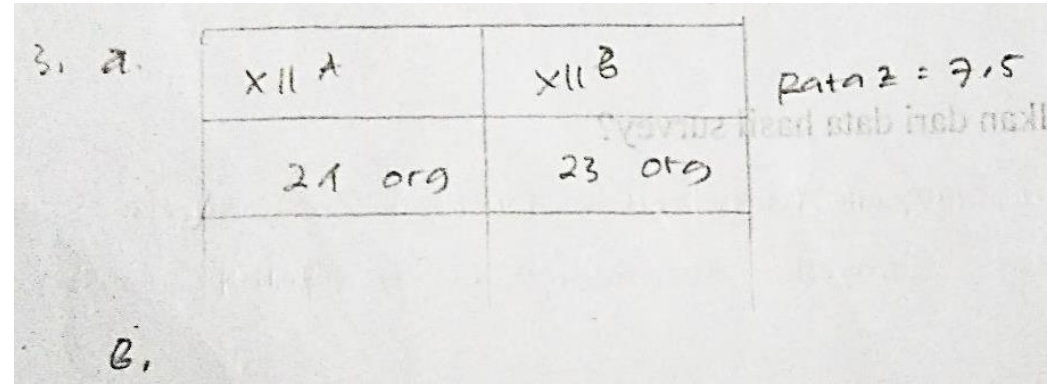

Gambar 3a. Jawaban siswa 1 pada soal no 3

Jawaban siswa 1 yaitu membuat model matematika dari soal cerita yang diberikan, kemudian menyimpulkan dengan mencari rata-rata terlebih dahulu. Jawaban ini sudah benar namun proses mencari nilai rata-rata tidak diuraikan dengan jelas. Pada jawaban soal no $3 \mathrm{~b}$ siswa membiarkannya tidak di isi, pertanyaan soal tersebut masih berkaitan dengan jawaban sebelumnya mencari rata-rata berdasarkan jawaban no 3a.

Jawaban siswa 2
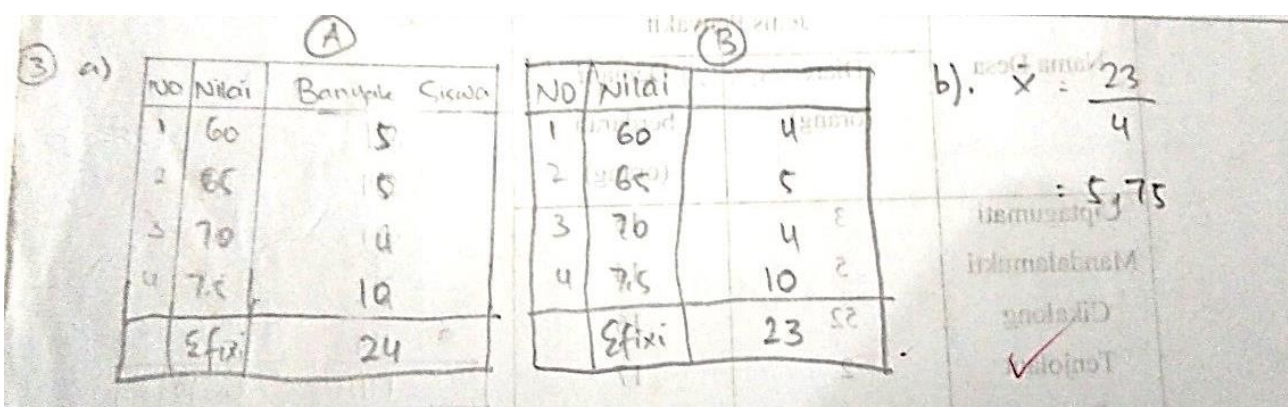

Gambar 3b. Jawaban siswa 2 pada soal no 3 
Analisis Kemampuan Komunikasi Matematis Siswa Smp Di Kota Cimahi Pada Materi Statistika, Niasih, Siti Romlah, Luvy Sylviana Zhanty

Jawaban siswa 2 pada soal no 3 yaitu sama membuat model matematika, namun pada jawaban ini siswa terkesan memperkirakan jawaban untuk membuat model matematika. Pada tabel tersebut siswa mengumpamakan dengan data nilai dan banyaknya siswa sehingga jumlahnya 24 dalam tabel pertama dan 23 dalam tabel kedua. Untuk jawaban 3b, siswa bermaksud mencari rata rata berdasarkan model matematika, namun jawaban tersebut salah karena tidak sejalan dengan perintah pada soal yang diberikan dan jawaban tersebut tidak disertai alasan yang jelas.

Kendala yang dihadapi pada soal no 3 adalah siswa kurang menguasai konsep atau materi, sehingga siswa belum mampu mengerjakan soal latihan. Siswa kesulitan dalam membuat model matematika dan menghitung nilai rata-rata yang diberikan. Soal no 3 juga menuntut siswa menyimpulkan berdasarkan jawaban yang telah dikerjakan, namun siswa lebih fokus kepada soal hitungan.

\section{Analisis soal no 4}

Butir soal keempat dengan indikator Mendengarkan, mendiskusi dan menulis tentang matematika adalah sebagai berikut:

Data usia 40 karyawan sebuah SMA disajikan dalam tabel berikut.

\begin{tabular}{|c|c|}
\hline $\begin{array}{c}\text { Usia } \\
\text { (tahun) }\end{array}$ & Frekuensi \\
\hline $25-29$ & 4 \\
\hline $30-34$ & 5 \\
\hline $35-39$ & 10 \\
\hline $40-44$ & 7 \\
\hline $45-49$ & 12 \\
\hline $50-54$ & 2 \\
\hline
\end{tabular}

a. Gambarkan Histogram dari tabel distribusi frekuensi berkelompok!

b. Apakah nilai modus dan median pada data tersebut berdekatan? Berikan penjelasannya!

Jawaban siswa

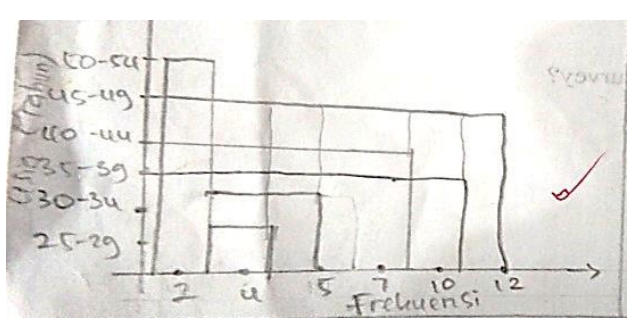

(a)

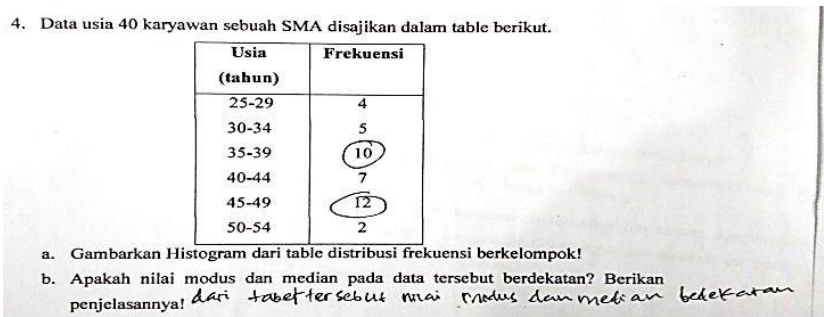

(b)

Gambar 4 (a) Jawaban siswa soal 4a (b) Jawaban siswa soal 4b 
Jawaban siswa untuk soal no 4 berdasarkan gambar 4a dan 4b menggambarkan histogram dan menarik kesimpulkan berdasarkan nilai modus dan nilai median pada tabel. Dari jawaban siswa tersebut dapat diketahui siswa belum mampu menggambar histogram dengan benar, jawaban siswa dalam gambar 4a kurang tepat, karena letak frekuensi seharusnya berada pada garis vertikal, namun siswa terbalik menempatkan. Untuk jawaban no $4 \mathrm{~b}$, siswa dituntut mencari nilai median dan modus kemudian menarik kesimpulan. Namun siswa cenderung menarik kesimpulan dari data yang diberikan pada soal saja tanpa menghitung terlebih dahulu. Jawaban tersebut dikatakan salah karena belum tentu nilai pada tabel dapat menjawab pertanyaan dengan benar. Kesulitan yang dihadapi siswa pada soal no 4 adalah penguasaan konsep atau materi sehingga siswa belum mampu mengerjakan soal latihan.

\section{Analisis soal no 5}

Butir soal kelima dengan indikator Membuat konjektur, menyusun argumen, merumuskan definisi dan generalisasi, sebagai berikut:

Sekelompok tim kesehatan melakukan survey terhadap penyebaran dua penyakit di masyarakat pada 5 desa di kecamatan Cikalongwetan sepekan ini berikut hasilnya disajikan dalam table di bawah ini!

\begin{tabular}{|c|c|c|}
\hline \multirow{2}{*}{ Nama Desa } & \multicolumn{2}{|c|}{ Jenis Penyakit } \\
\cline { 2 - 3 } & Diare (orang) & Demam Berdarah (orang) \\
\hline Ciptagumati & 3 & 15 \\
\hline Mandalamukti & 5 & 14 \\
\hline Cikalong & 52 & 16 \\
\hline Tenjolaut & 2 & 17 \\
\hline Puteran & 10 & 13 \\
\hline
\end{tabular}

a. Hitung nilai rata-rata dari penyebaran data penyakit di 5 desa berdasarkan hasil survey!

b. Apa yang dapat kalian simpulkan dari data hasil survey?

Jawaban siswa

a. Hitung nilai rata-rata dari penyebaran data penyakit di 5 desa berdasurkan hasil survey! $29 \cdot 5$

b. Apa yang dapat kalian simpulkan dari data hasil survey? Karna Surver

tosebus menuñukan nicai Rata-Rata yaitu 29,5 maka di burat kan menjadi 30

Gambar 5. Jawaban siswa soal no 5

Jawaban siswa pada gambar 5 yaitu siswa menjawab pertanyaan soal tanpa menghitung sehingga jawaban tidak disertai proses pengerjaannya. Untuk jawaban no $5 \mathrm{~b}$ siswa dituntut menarik kesimpulan dari tabel yang diberikan, jawaban tersebut mendekati benar namun tetap 
Analisis Kemampuan Komunikasi Matematis Siswa Smp Di Kota Cimahi Pada Materi Statistika, Niasih, Siti Romlah, Luvy Sylviana Zhanty

siswa tidak mengerjakan dengan prosesnya. Hal ini mungkin dikarenakan siswa sulit menguasai konsep rata-rata pada materi statistika tersebut.

Hasil analisis diatas sejalan dengan penelitian (Rahmawati, et. al., 2019) yang menemukan bahwa kemampuan komunikasi matematik pada siswa SMK di Kabupaten Bandung Barat masih termasuk kategori rendah, yang mana siswa masih kesulitan pada indikator menyatakan peristiwa sehari-hari dalam model matematika serta untuk indikator menghubungkan grafik dengan ide matematik. Hal ini juga menu jukan bahwa kesulitan siswa pada indikator komunikasi tersebut tidak hanya di alami siswa smp tapi juga dilami siswa SMK.

Permasalahan yang dihadapi siswa berdasarkan analisis soal dan wawancara peneliti adalah siswa mengganggap statistika terlalu bertele-tele karena harus melakukan pengumpulan, pengolahan data hingga fase membuat kesimpulan, hal ini juga yang jadi penyebab rendahnya kemampuan komunikasi matematis siswa pada indikator menyatakan peristiwa sehari-hari dalam model matematika serta untuk indikator menghubungkan grafik dengan ide matematik.

\section{SIMPULAN}

Berdasarkan pada hasil dan pembahasan, peneliti menemukan yang dapat disimpulkan dari beberapa kesalahan siswa ketika menjawab soal komunikasi matematis, adalah:

a. Kurangnya penguasaan konsep atau materi statistika.

b. Siswa kurang cermat dalam menyelesaikan soal komunikasi matematis.

c. Rendahnya keterampilan siswa dalam menarik kesimpulan.

d. Siswa menjawab soal tidak disertai dengan alasan yang jelas.

Dengan demikian, merujuk pada hasil analisis dari sampel kelas VIII di salah satu SMP di Kota Cimahi menunjukan bahwa tingkat kemampuan komunikasi matematis siswa dalam kategori kurang atau masih rendah.

\section{DAFTAR PUSTAKA}

Akbar, P., Hamid, A., Bernard, M., \& Sugandi, A. I. (2018). Analisis kemampuan pemecahan masalah dan disposisi matematik siswa kelas xi sma putra juang dalam materi peluang. Jurnal Cendekia: Jurnal Pendidikan Matematika, 2(1), 144-153.

Bernard, M. (2015). Meningkatkan kemampuan komunikasi dan penalaran serta disposisi matematik siswa SMK dengan pendekatan kontekstual melalui game adobe flash cs 4.0.Infinity Journal, 4(2), 197-222.

Bernard, M., \& Senjayawati, E. (2019). Developing the Students' Ability in Understanding Mathematics and Self-confidence with VBA for Excel. JRAMathEdu (Journal of Research and Advances in Mathematics Education), 1(1), 45-56. 
Chotimah, S., Bernard, M., \& Wulandari, S. M. (2018, January). Contextual approach using VBA learning media to improve students' mathematical displacement and disposition ability. InJournal of Physics: Conference Series (Vol. 948, No. 1, p. 012025). IOP Publishing.

Chotimah, S., Ramdhani, F. A., Bernard, M., \& Akbar, P. (2019). Pengaruh Pendekatan ModelEliciting Activities Terhadap Kemampuan Berpikir Kritis Matematik Siswa Smp Negeri Di Kota Cimahi. Journal on Education, 1(2), 68-77.

Dilla, R.S. (2014). Analisis Komunikasi Matematis Siswa SMP Pada Materi Segi Empat. Jurnal Ilmiah Nusantara of Research, Vol 5. No. 1, April 2018

Fahradina, N., Ansori, I.Bansu., Saiman. (2014). Peningkatan Kemampuan Komunikasi Matematis dan Kemandirian Belajar Siswa SMP dengan Menggunakan Model Investigasi Kelompok. Jurnal Didaktik Matematika ISSN: 2355-4185, Vol 1, No. 2, September 2017.

Hidayat, F., Akbar, P., \& Bernard, M. (2019). Analisis Kemampuan Berfikir Kritis Matematik Serta Kemandiriaan Belajar Siswa Smp Terhadap Materi Spldv. Journal on Education, 1(2), 515523.

Khadijah, A., Maya, R., \& Setiawan, W. (2018). Analisis Kemampuan Komunikasi Matematis Siswa SMP Pada Materi Statistika. JPMI (Jurnal Pembelajaran Matematika Inovatif), 1(6), 10951104.

Islamiah, N., Purwaningsih, W. E., Akbar, P., \& Bernard, M. (2018). Analisis Hubungan Kemampuan Pemecahan Masalah Matematis dan Self Confidence Siswa SMP. Journal on Education, 1(1), 47-57.

Maharani, S., \& Bernard, M. (2018). Analisis Hubungan Resiliensi Matematik Terhadap Kemampuan Pemecahan Masalah Siswa Pada Materi Lingkaran. JPMI (Jurnal Pembelajaran Matematika Inovatif), 1(5), 819-826.

Nurhayati, N., \& Bernard, M. (2019). ANALISIS KESULITAN SISWA DALAM PEMECAHAN MASALAH MATEMATIK SISWA KELAS X SMK BINA INSAN BANGSA PADA MATERI PERSAMAAN DAN PERTIDAKSAMAAN. Journal on Education,1(2), 497-502.

Nurjaman, A. (2015). Meningkatkan Kemampuan Komunikasi Matematik Siswa SMP Melalui Model Pembelajaran Kooperatif Tipe Think Pair Share (TPS). Jurnal Didaktik 9 (1)

Rahmawati, N. S., Bernard, M., \& Akbar, P. (2019). Analisis Kemampuan Komunikasi Matematik Siswa Smk Pada Materi Sistem Persamaan Linier Dua Variabel (SPLDV). Journal on Education, 1(2), 344-352.

Rohaeti, E.E. dkk. (2018) Meningkatkan Kemampuan Komunikasi Matematik Siswa kelas VIII SMP Negeri 2 Cariu Pada materi Sistem Persamaan Linear Dua Variabel dengan Pendekatan Realistic Mathematic Education (RME). JPMI (Jurnal Pembelajaran Matematika Inovatif), Vol 1, No. 3, Mei 2018. 
Analisis Kemampuan Komunikasi Matematis Siswa Smp Di Kota Cimahi Pada Materi Statistika, Niasih, Siti Romlah, Luvy Sylviana Zhanty

Setiawan, W. (2015). Meningkatkan Kemampuan Berpikir Kritis Matematis Siswa SMP Dengan Menggunakan Model Penemuan Terbimbing. Jurnal Ilmiah UPT P2M STKIP Siliwangi, Vol.2, No. 1, Mei 2015.

Sugandi, A. I., \& Bernard, M. (2018). Penerapan Pendekatan Kontekstual Terhadap Kemampuan Pemahaman Dan Komunikasi Matematis Siswa Smp. Jurnal Analisa, 4(1), 16-23.

Sumarmo. (2006). Penilaian Pembelajaran Matematika. Bandung: PT Refika Aditama

Umar. W. (2012). Membangun Kemampuan Komunikasi Matematis dalam Pembelajaran Matematika. Infinity Journal,1(1) 